\title{
Occurrence and significance of bonamiasis in European flat oysters Ostrea edulis in North America
}

\author{
R. A. Elston ${ }^{1}$, C. A. Farley ${ }^{2}$ \& M. L. Kent ${ }^{1}$ \\ ${ }^{1}$ Center for Marine Disease Control, Battelle/Marine Research Laboratory, 439 West Sequim Bay Road, Sequim, Washington \\ 98382, USA \\ ${ }^{2}$ National Marine Fisheries Service, Northeast Fisheries Center, Oxford, Maryland 21654, USA
}

\begin{abstract}
The protozoan blood-cell parasite Bonamia ostreae of the European flat oyster Ostrea edulis has caused extensive mortalities in France, the United Kingdom. The Netherlands, Spain, and Denmark. The discovery of the disease in 4 oyster populations in North America is the first documentation of the disease outside Europe. Ultrastructure of the parasite, inflammatory lesions in the affected oysters, and transmissibility patterns of the disease demonstrate the identity of the disease in Europe and North America. Current studies and reconstruction of historical records trace the origin of the disease to California (USA) and possibly an Atlantic North American site, followed by its spread within North America and to Europe, where it was first described in detail and recognized as a significant cause of oyster mortalities.
\end{abstract}

\section{INTRODUCTION}

A disease leading to extensive mortalities of the European flat oyster Ostrea edulis is caused by the protozoan parasite Bonamia ostreae of the oyster's blood cells. First described from oysters in France in 1979 (Comps et al. 1980), significant mortalities of the flat oyster have been attributed to the disease in a variety of European countries including France, Spain, England, Denmark, and The Netherlands (Balouet et al. 1983, Bucke \& Feist 1985, Van Banning 1985). The organism spreads readily within dense populations of oysters and is associated with cumulative mortality rates of up to $80 \%$ within 6 mo of introduction to a population (Poder et al. 1982, Balouet et al. 1983).

Although previous reports described separate and apparently different 'microcell' parasites and associated mortalities from the flat oyster and the Pacific oyster Crassostrea gigas in western North America (Katkansky et al. 1969, Katkansky \& Warner 1974, Glude 1975), the identity of these microcells, and their possible relation to Bonamia ostreae, has never been determined. We report here the first definitive evidence of the occurrence of $B$. ostreae disease in North America and associated flat oyster mortalities. Additionally, we include important observations on the prevalance of this significant disease in 9 separate stocks of oysters, and reconstruct historical information which demonstrates the probable route by which this serious disease spread within North America and subsequently to Europe.

\section{METHODS AND MATERIALS}

A total of 560 flat oysters Ostrea edulis from western North American locations which represented 9 separate stocks (Table 1) were brought into the laboratory and held separately by stock in a quarantine facility where they were placed in continuous flowing, sandfiltered, ultraviolet-irradiated seawater at $16^{\circ} \mathrm{C}$. Oysters were considered to be separate stocks for the purposes of these studies if they were collected from distinct locations and from a population whose recent history of geographic movements could be ascertained from records of regulatory agencies or shellfish farms. Each stock of oysters was held for observation for a minimum of $60 \mathrm{~d}$ (Table 1) (subsequently referred to as the 'live test'). Oysters were examined twice each week during the live test by testing the shell closure response of each individual. Moribund individuals were removed and processed for histological analysis 
using Davidson's fixative (Shaw \& Battle 1957) and routine methods for paraffin histology. Selected samples were processed for transmission electron microscopy using previously described methods (Elston \& Peacock 1984). Samples of the stocks of oysters in which the disease had not been detected at the end of the live test period were sacrificed and processed histologically. Remaining live oysters in stocks from which diseased individuals had been detected were not sacrificed since these were considered to be potentially valuable carriers for further definitive studies on the disease.

Thirty uninfected oysters were marked and held in the same aquarium as 55 oysters from an infected stock to determine the transmissibility of the disease. Moribund individuals were periodically removed and examined histologically.

\section{RESULTS}

\section{Pathology and identity of the etiologic agent}

Wet-mount preparations and histological sections of infected Ostrea edulis revealed numerous 2 to $3 \mu \mathrm{m}$ spherical organisms with a characteristic eccentric protoplasmic density within the blood cell cytoplasm (Fig. 1 \& 2). The infected blood cells typically accumulated in the vascular sinuses around stomach, style sac, and intestine. Infected blood cells were, however, observed in virtually all tissues. In heavily infected individuals, the blood cells containing the organisms were observed between digestive epithelial cells and in the lumen of digestive organs.

Fig. $3 \& 4$ show the typical ultrastructure of the microorganism. It includes a peripheral nucleolus in the organism's nucleus, large mitochondria with few tubular cristae and haplosporosomes which are dense bodies comprised of concentric laminations at their periphery and are about $215 \mathrm{~nm}$ in diameter. Fig. 3 shows the process of nuclear division in which the nuclear membrane is intact.

In addition to infected oysters, inflammatory lesions occurred in oysters in which the organism could not be detected (Table 1). These lesions consisted of accumulations of granulocytic amebocytes around digestive organs which appeared to contain cellular debris.

\section{Known distribution of the disease}

Table 1 lists the identity by geographic source of the oyster stocks tested, the length of the live test for each stock and the occurrence of the disease in each stock as determined by histological methods. During the live test, 3 stocks from Puget Sound, Washington (Stocks 1, $2 \& 3$ in Table 1 ), were confirmed to have carriers of the disease since it was detected in some of the moribund individuals from these stocks. All of the diseased oysters were 2 to 5 yr of age. In these 3 stocks, cumulative mortality (including what was considered to be terminal morbidity) ranged from 30 to $35 \%$ during the live test. Between 34 and $100 \%$ of the sick and dead oysters were positively diagnosed as having the disease. Of the remaining 6 stocks of oysters, no morbidity or mortality was observed in 4 stocks and the cumulative mortality in the other 2 stocks was 4 and $9 \%$. The Mud Bay stock was, however, infected, as determined by histological examination of the oysters at the end of the live test although no oysters died or became moribund

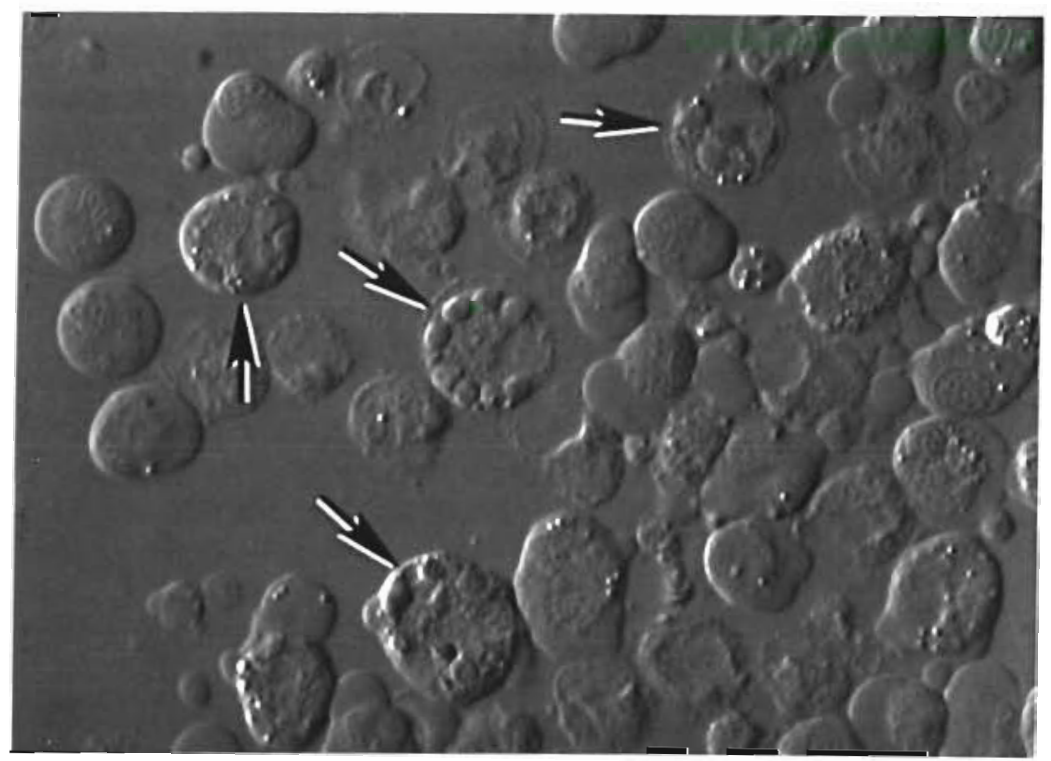

Fig. 1. Ostrea edulis. Nomarski differential interference micrograph of a live wet preparation of Bonamia ostreae infected blood cells (arrows); $1280 \times$ 
Fig. 2 to 4. Ostrea edulis. Fig. 2. Bonamia ostreae infected hemocytes (arrows); $1000 \times$; Hematoxylin and eosin. Fig. 3. Electron micrograph of $B$. ostreae showing dividing nuclei with nucleus membrane intact and peripheral nucleoli $(\mathrm{Nu})$; arrows: haplosporosomes; $40000 \times$. Fig. 4. Haplosporosome in B. ostreae cytoplasm; $120000 x$
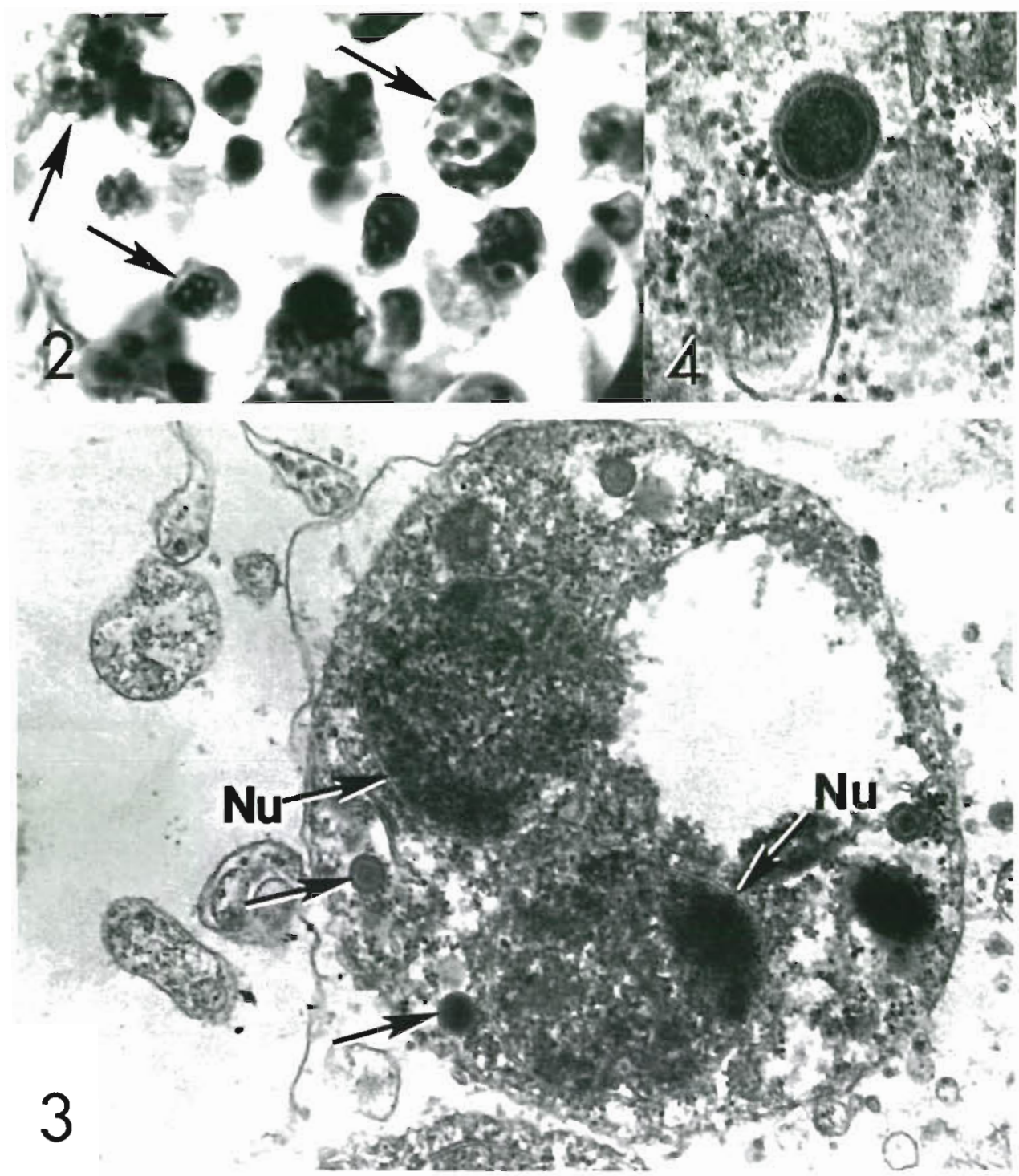

during the test. The parasite was not detected in any oysters from the other 5 stocks (Table 1 ).

The history of the stocks, as far as could be determined from available records, is as follows in reference to the stock numbers in Table 1: Stocks 1 to 3 originated from a now defunct shellfish hatchery located on Elkhorn Slough in California. Stock 4 was shipped from an unidentified European source to a shellfish hatchery in Maine, the progeny were then shipped to Liberty Bay, Washington; Stock 5 was shipped from Humboldt Bay, California, to Liberty Bay, Washington; Stock 6 was shipped from Maine to South Puget Sound, Washington, where it was likely mixed with infected Stock 1, 2 yr prior to examination at the laboratory; Stock 7 was from the same source as Stock 6 but was grown out in a different bay in Puget Sound (Table 1). Stock 8 was transferred from Maine to Humboldt Bay,
California, prior to its introduction to Washington. The infected Stocks 1 and 2 were shipped directly from the California source to Washington while Stock 3 was reported to have been shipped to a location in Oregon state prior to its final shipment to Puget Sound.

\section{Transmission of the disease}

Only 5 of the 30 uninfected Ostrea edulis exposed to Bonamia ostreae infected oysters died before the duration of exposure had reached $210 \mathrm{~d}$. The disease could not be diagnosed in any of these oysters. However, all of the remaining 25 oysters died between 210 and $266 \mathrm{~d}$ of exposure, and all were confirmed to have advanced cases of the disease by histological examination. Three of the 30 control oysters died during the 
Table 1. Ostrea edulis. Evaluation of North American stocks for presence of Bonamia ostreae disease

\begin{tabular}{|c|c|c|c|c|c|}
\hline \multirow[b]{2}{*}{ Stock identity } & \multirow[b]{2}{*}{$\begin{array}{l}\text { Length of } \\
\text { live test }\end{array}$} & \multirow[b]{2}{*}{$\begin{array}{c}\text { Mortality: } \\
\text { Proportion }(\%) \\
\text { of live test }\end{array}$} & \multirow[b]{2}{*}{$\begin{array}{c}\text { Number }(\%) \text { of } \\
\text { dead oysters } \\
\text { with bonamiasis }\end{array}$} & \multicolumn{2}{|c|}{$\begin{array}{c}\text { Histology of oysters live at end of test } \\
\text { period: proportion }(\%)\end{array}$} \\
\hline & & & & $\begin{array}{c}\text { Inflammatory } \\
\text { lesions }\end{array}$ & $\begin{array}{l}\text { Bonamia } \\
\text { organisms }\end{array}$ \\
\hline $\begin{array}{l}\text { (1) South Puget } \\
\text { Sound--1 }\end{array}$ & $6 \mathrm{mo}$ & $25 / 72$ & $19 / 25(76)$ & $N^{b}$ & NA \\
\hline $\begin{array}{l}\text { (2) South Puget } \\
\text { Sound }-2\end{array}$ & $2 \mathrm{mo}$ & $8 / 25 \quad(32)$ & $8 / 8(100)$ & NA & NA \\
\hline $\begin{array}{l}\text { (3) North Puget } \\
\text { Sound }\end{array}$ & $7 \mathrm{mo}$ & $38 / 126(30)$ & $13 / 38\{34\}$ & NA & NA \\
\hline (4) Liberty Bay-1 & $5 \mathrm{mo}$ & $5 / 120(4)$ & $0 / 5$ & NA & NA \\
\hline (5) Liberty Bay -2 & $6 \mathrm{mo}$ & $7 / 80 \quad(9)$ & $0 / 7$ & $18 / 35(51)$ & $0 / 35$ \\
\hline (6) Mud Bay & $2 \mathrm{mo}$ & $0 / 27$ & - & $2.5 / 27(9.3)$ & $6 / 27(22)$ \\
\hline (7) Oakland Bay & $2 \mathrm{mo}$ & $0 / 28$ & - & $18 / 27(67)$ & $0 / 27$ \\
\hline $\begin{array}{l}\text { (8) Humboldt Bay } \\
\text { California }-1\end{array}$ & $2 \mathrm{mo}$ & $0 / 52$ & - & $7 / 35(20)$ & $0 / 35$ \\
\hline $\begin{array}{l}\text { (9) Humboldt Bay } \\
\text { California-2 }\end{array}$ & $2 \mathrm{mo}$ & $0 / 30$ & - & $8 / 30(27)$ & $0 / 30$ \\
\hline $\begin{array}{l}\text { ¿Stocks } 1 \text { through } \\
{ }^{b} \mathrm{NA}: \text { not applicab }\end{array}$ & mashin & tate locations & & & \\
\hline
\end{tabular}

live test but the parasite was not detected in these or any of the remaining 27 oysters at the termination of the experiment.

\section{DISCUSSION}

Comparison of both the pathological manifestations of the disease and the specific structures of the etiologic agent observed in this study with information in earlier reports of the disease in Europe (Comps et al. 1980, Balouet et al. 1983, Bucke \& Feist 1985) confirm that the disease in North America is caused by Bonamia ostreae. The localization of the 2 to $3 \mu \mathrm{m}$ organism in hemocytes, the subsequent inflammatory response, the peripheral nucleolus of the organism, the retention of the nuclear membrane during division, the presence of haplosporosomes, and the transmissibility of the disease are key features in establishing this identity. Furthermore, the subsequent appearance of bonamiasis at locations on 2 continents which received Ostrea edulis seed from the Elkhorn Slough, California site (see below) is supporting epizootiological evidence of the identity of the disease in North America and Europe.

Although sporulation of the parasite has not been reported, it has been suggested that Bonamia ostrea is a haplosporidan due to the presence of haplosporosomes (Pichot et al. 1980). However, similar organelles occur in the Myxozoa and thus spore structure (i.e. multicellular spores without polar capsules) should be used to define its appropriate taxon. Because no spores have been detected, its placement in the phylum Ascetospora is tenuous. Poder et al. (1982) showed that the infection can be spread directly from oyster to oyster. Therefore, if a reservoir host exists in which sporulation occurs, it is not needed for transmission of the disease.

The occurrence of the inflammatory lesions in both infected and apparently uninfected oyster stocks is of interest. Bucke \& Feist (1985) make note of hemocytic proliferation and the unclear relation of this to infestation with the parasite. Further studies should investigate any possible relation of the inflammation with cryptic developmental stages of the disease. Since inflammatory lesions of unknown cause are not uncommon in oysters, the presence of these without a definitive parasite identification cannot be taken to indicate the presence of Bonamia ostreae.

The seriousness of the disease in Europe indicates that it is a significant cause of oyster mortalities and that action should be taken to eradicate the disease or at least prevent its further spread. The disease is reported to result in oyster mortalities of up to $80 \%$ with a detectable prevalence of $60 \%$ in affected populations (Balouet et al. 1983). The disease can result in moribund oysters following as short as a 3 to 4 mo exposure to infected oysters under experimental conditions but may require longer to spread in less dense field populations (Poder et al. 1982, Van Banning 1982). Thus, the transmission studies reported here are consistent with earlier studies.

Some hope for eradication of the disease in well- 
defined infected areas is indicated in the ongoing studies conducted by Van Banning (1982, 1985). In these studies, in which infected oysters were removed from beds on the Yerseke Bank in the Netherlands, prevalence of infection was reduced from between 4 to $24 \%$ to zero over a $3 y r$ period in 6 locations. Unexpected recurrence of the disease was reported in early studies but over the longer term, the eradication measures may be effective. Clearly, constant monitoring for the infection until no infected oysters have been detected for a period of several years is essential to any effective eradication program.

The apparent direct source of the infected oyster stocks in Washington was the Elkhorn Slough, California source. This same location was the source of large amounts of Ostrea edulis seed transferred to France in the years prior to the detection of the disease there. A 'microcell' disease of $O$. edulis was reported to occur in Morro Bay, Elkhorn Slough and Drake's Estero but not in Tomales Bay or Humboldt Bay, California, in 1966 and 1967 (Katkansky \& Warner 1974). One of the authors of the present paper (C. A. Farley) made the original histological confirmation of the microcell condition in 1966 and later suggested that it was identical with bonamiasis in Europe based on ultrastructural observations made on the deparaffinized histological sections. The condition was detected in all gaping oysters from Morro Bay and in 30 to $58 \%$ of the live oysters from the 3 locations. Mortality associated with the condition was high in a variety of populations studied during the 1960 s and reached $100 \%$ within 12 mo in oysters planted in Elkhorn Slough in March of 1966. These brief descriptions given of the pathological manifestations of the disease strongly suggest that it was bonamiasis. The infected stocks identified in Puget Sound (Stocks 1, 2 \& 3), all of which originated from the Elkhorn Slough shellfish hatchery, were apparently descendants of a stock transferred there from Tomales Bay in 1965 (Katkansky \& Warner 1974). Although the same authors report shipments of $O$. edulis from the Milford (Connecticut, USA) laboratory to other sites in California in 1963, 1964 and 1965, it is not certain from that report if the Elkhorn Slough oysters were descendants of the Milford stock, although this seems likely. Thus, while the Elkhorn Slough, California, source can be implicated in the spread of the disease in both North America and Europe, the prior history of the disease remains difficult to reconstruct. Examination of archive specimens of $O$. edulis from the northeastern United States may further elucidate the source of the disease.

The seriousness of this disease and its association with 'microcells' was recognized in California at least as early as 1966 and was documented in the scientific literature in 1969 (Katkansky et al. 1969). In spite of international concern by government agencies for the containment of infectious shellfish diseases, this documentation was not sufficient to prevent the introduction of the disease into Europe in the late 1970s. More effective disease control measures will require educational measures for the shellfish industry and mutually supportive interactions between government and industry.

Acknowledgements. The Marine Research Laboratory is part of the Pacific Northwest Laboratory, which is operated for the Department of Energy by Battelle Memorial Institute under Contract DE-ACO6-76RLO 1830

\section{LITERATURE CITED}

Balouet, G., Poder, M., Cahour, A. (1983). Haemocytic parasitosis: morphology and pathology of lesions in the French flat oyster, Ostrea edulis L. Aquaculture 34: 1-14

Bucke, D., Feist, S. (1985). Bonamiasis in the flat oyster, Ostrea edulis, with comments on histological techniques. In: Ellis, A. E. (ed.) Fish and shellfish pathology. Proceedings of a Symposium, 20-23 September 1983, at Plymouth Polytechnic, Plymouth. Academic Press, London, p. 387-392

Comps, M., Tige, G., Grizel, H. (1980). Etude ultrastructural d'un prostiste parasite de l'huitre plate Ostrea edulis L. C.r Acad. Sci., Päris 290, (ser. D) 383-384

Elston, R. A., Peacock, M. G. (1984). A rickettsiales-like infection in the Pacific razor clam, Siliqua patula. J. Invertebr. Pathol. 44: 84-96

Glude, J. B. (1975). A summary report of Pacific coast oyster mortality investigations. In: Proceedings of the Third U.S.Japan Meeting on Aquaculture at Tokyo, Japan, October 15-16. Special Publication of Fishery Agency, Japanese Government and Japan Sea Regional Fisheries Research Laboratory, Niigata, Japan. p. 1-28

Katkansky, S. C., Dahlstrom, W. A., Warner, R. W. (1969) Observations on survival and growth of the European flat oyster, Ostrea edulis, in California. Calif. Fish Game 55: $69-74$

Katkansky, S. C., Warner, R. W. (1974). Pacific oyster disease and mortality studies in California. Marine Resources Technical Report No. 25, California Dept. of Fish and Game, Long Beach

Pichot, Y., Comps, M., Tige, G., Grizel, H., Rabouin, M.-A. (1980). Recherches sur Bonamia ostreae gen. n., sp. n., parasite nouveau de l'huitre plate Ostrea edulis L. Rev. Trav. de l'Institut des Pêches maritimes 43: 131-140

Poder, M., Cahour, A., Balouet, G. (1982). Hemocytic parasitosis in European oyster Ostrea edulis L.: pathology and contamination. In: Payne, C. C., Burges, H. D. (ed.) Invertebrate pathology and microbial control. Proceedings, IIIrd International Colloquium on Invertebrate Pathology, XVth Annual Meeting of the Society for Invertebrate Pathology, September 6-10, 1982, at University of Sussex, Brighton, U.K., p. 254-257

Shaw, B. L., Battle, H. I. (1957). The gross and microscopic anatomy of the digestive tract of the oyster Crassostrea virginica (Gmelin). Can. J. Zool. 35: 325-347

Van Banning, P. (1982). Some aspects of the occurrence, importance and control of the oyster pathogen Bonamia 
ostreae in Dutch oyster culture. In: Payne, C. C., Burges, H. D. (ed.) Invertebrate pathology and microbial control. Proceedings, IIIrd International Colloquium on Invertebrate Pathology, XVth Annual Meeting of the Society for Invertebrate Pathology, September 6-10, 1982, University of Sussex, Brighton, U.K., p. 261-265
Van Banning, P. (1985). Control of Bonamia in Dutch oyster culture. In: Ellis, A. E. (ed.) Fish and shellfish pathology. Proceedings of a Symposium, 20-23 September 1983, at Plymouth Polytechnik, Plymouth, U.K. Academic Press, London, p. 393-396

Responsible Subject Editor: Dr. G. Lauckner; accepted for printing on October 30, 1986 